\title{
HAITIAN IMMIGRATION NETWORK FOR FRENCH GUIANA: THE NORTHERN BRAZILIAN AMAZON ON THE DIASPORA ROUTE ${ }^{l}$
}

\author{
REDE DE IMIGRAÇÃO HAITIANA PARA A GUIANA FRANCESA: 0 \\ NORTE DA AMAZÔNIA BRASILEIRA NA ROTA DA DIÁSPORA
}

\author{
Paulo Gustavo Pellegrino Correa² \\ Andrevil Isma ${ }^{3}$ \\ Eliane Superti ${ }^{4}$ \\ Ítalo Allan Maia Gouvêa ${ }^{5}$
}

\begin{abstract}
The intensity of the Haitian migratory flow to South America increased with the earthquake of 2010 and included Brazil not only as a destination country, but also as a route to French Guiana. The Franco-Amapaense border (Amapá/Brazil French Guiana/France), previously not accessed by this flow in the northern Brazilian Amazon, became strategic. This paper presents the results of research conducted between 2015 and 2017 on the modus operandi of Haitian migration through this new route, its mechanisms and forms of action. The approach of the phenomenon came from the perspective of migratory networks and the investigation was based on data
\end{abstract}

1 This research was subsidized with the support of CAPES-PRÓ-DEFESA, edict 031/2013, and was developed in the context of the project "Transfronteirizaçôes na América do Sul: dinâmicas territoriais, desenvolvimento regional, integraçăo e defesa nas fronteiras meridional e setentrional do Brasil". The results of this research also subsidized the master's thesis and coursework completion of two of the authors.

2 Graduaçâo em Ciências Sociais. Mestre em Ciência Política pela Universidade Federal de Sâo Carlos (UFSCar). Doutor em Ciência Política na mesma instituiçâo. Pesquisador visitante na Universidade de Waikato, Nova Zelândia (2012) e Professor Convidado na University of West Indies (2017), e Pesquisador visitante no Kimberly Green Latin American and Caribbean Center na Florida International University. Possui curso de aperfeiçoamento pela National Defense University (EUA) na área de segurança e defesa: \&quot;Strategy and Defense Policy\&quot; (2008) e \&quot;Strategy and International Security Course\&quot; (2011). Pesquisador do Observatório das Fronteiras do Platô das Guianas (OBFRON). Tem experiência na área de Ciência Política (Política Externa Brasileira) e Relaçôes Internacionais (Paz, Defesa, e Segurança). Professor de Segurança Internacional e Política Externa Brasileira no curso de Relaçōes Internacionais da Universidade Federal do Amapá com pesquisa direcionada às questōes de segurança na regiăo das Guianas. Professor efetivo do Mestrado em Estudos de Fronteira (PPGEF) na Universidade Federal do Amapá. Professor colaborador do Mestrado em Desenvolvimento Regional da Amazônia (PPG-DRA) da Universidade Federal de Roraima. paulogustavo1978@gmail.com

3 Holds a master's degree in Environmental Law and Public Policy at the Federal University of Amapá. Researcher of the Research Group on Social Rights, Culture and Citizenship. iandrevil@yahoo.com

$4 \quad \mathrm{PhD}$ in Social Science and Professor of Political Science at the Federal University of Amapá (UNIFAP). Researcher at the Observatory of Guyana Shield Borders (OBFRON).esuperti@gmail.com

5 Holds a bachelor's degree in International Relations at the Federal University of Amapa, is a Junior Researcher of the Research Group on Social Rights, Culture and Citizenship. italogouvea7@gmail.com 
collection and systematization, reports of network agents and bibliographic research. The results obtained allow us to affirm that the migratory network constituted an important part of its structure in the Brazilian frontier territory.

KEYWORDS: Haitian Immigration. Diaspora route. French Guiana. Amapá.

RESUMO: A intensidade do fluxo migratório haitiano para a América do Sul aumentou com o terremoto de 2010 e incluiu o Brasil náo apenas como um país de destino, mas também como rota para a Guiana Francesa. A fronteira franco-amapaense (Amapá/ Brasil - Guiana Francesa/França), anteriormente năo acessada por esse fluxo no norte da Amazônia brasileira, tornou-se estratégica. O presente artigo apresenta os resultados da pesquisa realizada entre 2015 e 2017 sobre o modus operandi da migraçáo haitiana por meio dessa nova rota, seus mecanismos e formas de açâo. A abordagem do fenômeno partiu da perspectiva das redes migratórias e a investigaçâo baseou-se na coleta e sistematizaçăo de dados, relatos de agentes de redes e pesquisa bibliográfica. Os resultados obtidos nos permitem afirmar que a rede migratória constituiu parte importante de sua estrutura no território da fronteira brasileira.

PALAVRAS-CHAVE: Imigraçăo haitiana. Diáspora. Guiana Francesa. Amapá.

\section{INTRODUCTION}

This paper discusses the modus operandi of the Haitian migratory process for French Guiana whose route is the state of Amapá in northern Brazil. Considering the complexity of the migratory phenomenon, we opted for an interdisciplinary approach to identify migratory networks, observing the individual, family and community dimensions. The research was based on bibliographical research, survey and systematization of data and reports of immigrants obtained during fieldwork conducted along the migratory route between Macapá, capital city of the state of Amapá, and Cayenne, capital city of French Guiana.

The issue concerning international migration has gained more and more space in academic and media debates. The humanitarian crisis on the European continent is the biggest challenge faced by the bloc's representatives since the creation of the European Union. The daily influx of mostly illegal immigrants from much of Africa and the Middle East remains a challenge for political actors in these parts of the world. In the American continent, the intense immigration of Venezuelans to neighboring countries and the current restrictive and controversial policies of the United States government point to the increase of international tensions and emphasize that the globalization process re-defined the borders, making them more accessible for the circulation of goods and financial capital, but has not kept the same logic for the circulation of people from poor countries. In this scenario there are historical elements, typical of migration processes: misery escape; political persecution; wars. But there are also new elements such as "climate refugees" - victims of natural disasters such as the earthquake that rocked Haiti in 2010 and furthered the displacement of Haitians - and others that were redefined as an example of supranational networks support for the immigration process. 
All these elements are present in Haitian immigration, whose flow has been so intense that it was considered a diaspora (BERNATT et al., 2016; HANDERSON, 2015). Since independence, the country has been marked by power struggles, institutional instability, coups d'état, concentration of wealth, accentuated misery, illiteracy and international interventions (North American in 1915-1934 and UN from 2004 to 20176).

It is under this historicity of the Haitian socio-political formation that the diaspora emerges as the driving force behind the search for better living conditions for individuals and families. Immigration in Haiti is an important mechanism of the economy. It represents a survival strategy for individuals and families, access to basic services and goods. That is, it makes possible the maintenance, even productive, of the relatives who remained in their origin society. Massey et al., (1993, p. 438) drew attention to this family strategy:

In poor countries the needed funds may also be difficult to borrow because the family lacks collateral to qualify for a loan, because there is a scarcity of lending capital, or because the banking system provides incomplete coverage, serving mainly the needs of the affluent. For poor families, the only real access to borrowing is often from local moneylenders who charge high interest rates, making transactions costs prohibitive. Under these circumstances, migration again becomes attractive as an alternative source of capital to finance improvements in productivity and ensure stability in consumption, and the family has a strong incentive to send one or more workers abroad to accumulate savings or to transfer capital back in the form of remittances.

Not only the families, but the country itself benefits from international remittances. Haiti is the poorest country in the Americas (WORLD BANK, 2011) and remittances can reduce the chronic trade deficit. According to a survey carried out by the NGO International Crisis Group (2007), the estimate is that the percentage of international remittances in relation to GDP in 2007 was around 30-35\%, ahead of official development assistance and agriculture, which employed, before the earthquake of $2010,47 \%$ of the working population. According to the WORLD BANK (2011), immigrant remittances accounted for approximately $25 \%$ of the country's GDP in 2011. However, while on the one hand the immigration strategy provides financial resources, on the other hand it removes qualified human resources from the country. This makes Haiti the second country in the world regarding skilled labor exporting, behind only of the Co-operative Republic of Guyana. According to the World Bank report, in 2010, among those who received higher education in the country, 85\% were abroad (WORLD BANK, 2011).

The already intense immigration stimulus was further increased by the natural catastrophe of 2010 and an important part of the flow went to South America, including Brazil. The French Overseas Department (DOM), or GF, was already a traditional destination of this migratory movement, but it becomes more voluminous and takes on a new dynamic (GRANGER, 2017). According to Piantoni (2011), in 2009 the Haitian

6 The United Nations Stabilization Mission in Haiti (MINUSTAH) was established on April 30, 2004, by the UN Security Council Resolution 1542 and aimed at restoring the country's security and institutional normality after successive episodes of political turmoil and violence that culminated in the departure of the then President Jean Bertrand Aristide to exile. 
population was the most populous foreign nationality in French Guiana ${ }^{7}$, amounted to more than $10 \%$ of the country's total population. The increase of the flow added to internal issues, led France to increase the control of immigrants entering the French Overseas Department (DOM). Haitians usually arrived through Suriname, considered the gateway to the Caribbean and Amazonian migrations in GF, but with the increased control and distribution of migratory flow through South America, they now also transit through Brazil, a country that has become a new destination concerning the Haitian migratory network.

There are cultural aspects between French Guyana and Haiti that bring them closer together. The history of the social formation of the Caribbean region marked by the condition of former colonies and slavery, the common language, and both are designated "creole worlds" community already established by previous migratory processes that form entire neighborhoods in the capital of French Guiana, as well as economic and social factors, since, even facing the current crisis of unemployment, the Human Development Index (HDI) of French Guiana is the highest among the countries of the Guiana Plateau (DUARTE, 2016).

This paper will discuss aspects of this new dynamic of Haitian immigration to GF. Our interest here is to analyze the formation of the new route that includes the state of Amapá - located in the northern Brazilian Amazon and the area of the triple international border Brazil / GF / Suriname - regarding the strategies, mechanisms and forms of action that operate the Haitian migratory network in this region.

The work is divided into three parts. In the first part we present the design of migratory networks as a reference to the proposed approach. Secondly, based on the fieldwork, we examined the constitution of the new route to identify agents, institutions and structures that allow us to characterize it as part of the Haitian migratory network. Finally, as final considerations, we define the modus operandi of Haitian immigration to GF on the route of the northern Brazilian Amazon.

\section{MIGRATION NETWORKS AS AN ANALYSIS FRAMEWORK}

The use of the concept of "networks" for the analysis of the migratory phenomena was an extension and complexification of the definition constructed in the 1960s by Australian authors of the migratory chains. According to Truzzi (2008), the term "migratory chain" was used to explain the movement in which aspiring migrants were influenced and became aware of the difficulties, forms of displacement, housing and job opportunities by former migrants. The design of migratory networks has maintained

$7 \quad$ Officially, the Surinamese are the first foreign nationality registered in French Guiana, the Haitian population is the second. But sources from the Préfecture (representation of the French State in Cayenne), from the NGOs and census data from the French National Institute of Statistics from 1974 to 2009, allowed the researcher Frédéric Piantoni to estimate the population of Haiti in 23,654 in 2009. The difficulty in having the exact data lies in the secrecy of national statistics, including in the school sector, where data on nationality and ethnicity are prohibited, as well as the fact that there are illegal migrations.

8 Common in Francophone literature, "creole world" refers to notions of "hybridism" and cultural mixing. 
the importance of the role of emigrants in their ability to influence future immigrants in the society of origin, but has also brought other agents, their functions and social relations to the analysis. For Kelly (1995, p. 219), migratory networks can be defined as "groups of individuals who maintain recurrent contact among themselves, through occupational, familial, cultural or affective ties. In addition, they are complex formations that channel, filter and interpret information, articulate meanings, allocate resources and control behaviors".

The line that sews the "fabric" of the migratory network, and propels it, is information. It is fundamental for making decisions about whether to migrate or not, when, where, at what financial cost, and by what path. In contemporary society, the way information is organized and disseminated intersects the idea of migratory networks with the understanding of a networked society.

According to the Spanish sociologist Manuel Castells (1999), the networked society has its origins in the 1970s, in the Silicon Valley (California). Organized around information technology, in line with the global economy and global geopolitics, it has materialized new forms of production, communication, management and way of life. For the author, the social structure of the contemporary world uses tools developed by the informational paradigm and the bases of this new technological structure are based on increasing the human capacity to access and process information. The agents and institutions make daily use of the informational tools (Internet, WhatsApp, Facebook, among many others), which are developed by the new paradigm in their social practices of interactions in an interdependent and globalized world. In other words, the establishment of the network society ${ }^{9}$ enables the exchange of real-time information from anywhere on the connected planet, ensuring operative functionality of the global economy and new dynamics for social relations.

The networked society, insofar as it is connected, conveys and circulates global information in real time, subsidizes specific networks such as the migratory one, mainly in its movement of expansion and retraction. So, "information about opportunities or difficulties flows, which self-regulates the system. Thus, each information about an individual in his or her trajectory influences the whole system" (TRUZZI, 2008, p. 206).

This migratory network movement takes place through its "nodes". Networks have no center, only nodes. These nodes are points of contact, connection and distribution. Some are bigger and more important; however, all nodes are critical to network existence. When a node loses relevance or becomes unable to fulfill its function, the network reconfigures itself, deletes it, and creates new ones. Thus, if information composes the system of the network, it is the network in its entirety - as a flexible, yet structured, form of social relations - that provides the reference context for the agent to make decisions. That is, it's in the network context that the migrant, individually or in a family nucleus, makes his choices from the normative reality around him, as well as the set of social relations of the network.

9 Castells (1999) defines network as a set of interconnected nodes. Networks are open structures capable of expanding unlimitedly, integrating new nodes as long as they can communicate within the network, that is, provided they share the same communication codes. 
In this conception, the emigrant is an agent who makes choices - from a structured reality and the information he accesses - and mobilizes relational resources to achieve his goals, that is, he mobilizes and adds social capital ${ }^{10}$ to enable the emigration process (TRUZZI, 2008). Although a choice takes economic and variable elements into consideration, such as cost-benefit, these are not the only ones. Cultural and social variables make up the set of determinants concerning decision making.

When analyzing the migratory phenomenon from the perspective of networks, what is sought is to understand the role of the agent and social relations that are the basis of the decision to start from the society of origin, to move and establish itself in the receiving society. This perspective considers aspects that are not present in the classical interpretation of the migratory movement determination through structural conditions of the origin and destination regions of these immigrants and opposes the individualistic analysis of the rational choice by benefit maximization. The proposal is to analyze the social action considering it, as Levi $(2001$, p.98) points out, the "(...) result of constant negotiations, manipulations, choices and decisions of the individual in light of a normative reality that, although comprehensive, offers, however, multiple possibilities of conduct and individual interpretations". In this way, we try to understand the actions and social relations of the agents that give life to migratory movements without disregarding the structured reality in which they are inserted.

The individual and his/her relations are the focus of analysis and, as Truzzi (2008) indicates, this means a clear choice for micro-history to understand the meanings attributed by the agents, their actions and the sharing of the codes of meanings that form the reference context and shape behaviors and interpretations of the agents along the network, that is, social relations.

Although the focus of this work is not to analyze the entire Haitian immigration network to French Guiana, since our cut-off limits us to the analysis of the formation of the new route through Amapá, that is, a network node, the migratory network approach allowed us to unveil multiple agents in an articulated and solidary movement from the origin, through "transit territories", until the final destination. These agents are individuals and family groups of different nationalities and backgrounds, non-governmental organizations (NGOs), smugglers or "border crossers", taxi drivers, catraieiros ${ }^{11}$ and the receiving Haitian community in the territory of destination. Family, commercial (legal and illegal) and humanitarian aid relations spread throughout the network and form their system.

10 Pierre Bourdieu (1980) defined social capital as "the set of current and potential resources that are linked to the possession of a durable network of more or less institutionalized relations of inter-knowledge and interrecognition".

11 Catraieiros are owners or people that conduct a small motorized boat called catraia. 


\section{THE HAITIAN MIGRATION NETWORK ON THE NORTHERN BRAZILIAN AMAZON ROUTE}

To understand the use of the Haitian migratory route that passes through the Brazilian state of Amapá towards the French Overseas Department (DOM), 74 interviews were conducted with immigrants in Cayenne, capital of French Guiana, who emigrated between 2010 and 2014 and used this specific route. Of these, 54 were men and 20 were women between the ages of 24 and 35. Two middlemen were also interviewed in Macapá, capital of Amapá, who represent the Haitian Association in French Guiana and the NGO La Cimade, and all of them chose to preserve their identity, under some justifications such as: that the entry into the DOM occurred clandestinely; the role they played to enable the arrival; or the maintenance of living conditions of illegal immigrants in GF (field interview, 2015).

In Haiti, as in many other underdeveloped countries, immigration usually takes place in two stages. First is the internal displacement, from rural to urban. The livelihood of Haiti is mostly agricultural, $65 \%$ of its population is in the countryside, despite a high concentration of land - only $2 \%$ of the population owns $55 \%$ of agricultural production (ISMA, 2016, p. 43). In cities, underemployment or informal employment accounts for almost $90 \%$ of occupations, accumulating large numbers of impoverished workers which live below poverty line (ISMA, 2016, p. 44). Among those interviewed, 66 experienced this first move from the countryside to the city, with the majority (63) from southern Haiti. The exception was 3 men and 5 women who migrated directly from their places of origin.

The trip to the city is already part of the decision to emigrate. The women who reported not having made this first move, emigrated from their original localities in the rural environment and had companions or brothers in the destiny that organized their travel. The three men who also migrated directly came from urban centers. According to the reports, future emigrants seek in the cities formal and informal jobs or autonomous occupations that allowed them to accumulate some money to subsidize part of the departure costs and help family members. In addition, in the cities the circulation of information is more dynamic and the articulation with the migratory network is facilitated by internet connection. That said, we can realize how the network society can be more active in these spaces.

During this period in the city, the applicant for emigration plans the process or part of it. The migration network to be accessed depends on the contacts that the future immigrant has and the costs he and his supporters throughout the network can afford. European or North American countries such as the United States and Canada demand more investment and a denser articulation with the social capital of the future immigrant in face of the risks of the migration process and the difficulties of insertion in the destination society. Having friends or relatives at the place of destination, according to the interviewees was decisive to move. They are the ones that help define the route, the supporting points during the journey, the connections with the middlemen or smugglers, where to stay on arrival and how to enter the labor market of the destination society. 
The objective conditions of the political-social and economic reality of the Haitian country are important variables of decision-making to migrate, but they are tempered by the migration culture. Migrating is not something exceptional or simply a rupture. In the interviews of all emigres, the possibility of migrating was always present in their individual life options, as well as in their family nucleus. Family ties are reinforced with the possibility that the whole nucleus benefits from the migration of its members and, in addition, all had relatives outside the country of origin. The table 1 shows the reasons stated by the interviewees to leave Haiti.

Table 1 - Reasons for migration to French Guiana

\begin{tabular}{lccc}
\hline Reason for migration & Men & Women & Total \\
\hline Haiti Economy & 16 & 11 & 27 \\
Family emigrants & 19 & 6 & 25 \\
Emigrated friends & 14 & 3 & 17 \\
Politics of Haiti & 5 & 0 & 5 \\
Total & $\mathbf{5 4}$ & $\mathbf{2 0}$ & $\mathbf{7 4}$ \\
\hline
\end{tabular}

Source: Research questionnaire applied in 2015.

Although the internal economic issue motivates a significant part of the migrants (36\%), when added the influence that relatives and friends who already emigrated have on the decision of the aspirant to migration, it sums up to $57 \%$ of the total. This reinforces the role that emigrants play in their hometown societies, stimulating new emigrations. Local politics appeared in $7 \%$ of the answers, all by men who reported to undergo political persecution in the country of origin ${ }^{12}$.

The economic strategies to materialize the migration plan, according to the interviewees, range from individual and family economies to the origin of financing mechanisms organized in the network. That is, as a rule, the immigrant does not bear all the costs of the process alone. These costs are distributed along the network between family members, friends and acquaintances who are in the country of origin, the points of support that receive the immigrant in transit and the receiving community in the destination. Between the migrant and his supporters there is a tacit "migration contract" to make sure that costs will be paid once settled in the detained society. But, with the family in the country of origin and the receiving community, this agreement goes beyond and engenders a permanent link that perpetuates the network.

Among those interviewed, all stated that they were committed to financially assist family and friends in both Haiti and GF, including to receive new immigrants from these groups. Among those who needed financial assistance or other costs (food, accommodation, transportation) from friends and acquaintances in the process of moving beyond family members (45), they had already made the payments or were still doing so. For Guilmoto and Sandron, the migration contract is fundamental to keep the network in operation:

12 Although the research did not deepen this issue, and it is not possible to affirm the veracity or not of the information, it is worth emphasizing that having political persecution as a motive for immigration allows the application for asylum in DOM. 


\begin{abstract}
The participants in the migration transaction are linked up via a tacit agreement on the distribution of the costs and the gains or benefits from the immigration: the migration contract. This contract seeks to secure the family or origin beforehand against the possibility of opportunism on the part of migrant, who might, once successfully established in the destination, break his ties to his kin. For the family, and more generally for the community, such behavior puts the entire system in danger, since the assistance provided to future migrants could end up as lost investments (GUILMOTO; SANDRON, 2001, p. 144-145).
\end{abstract}

The most common way to start the process is to leave the country without the necessary documentation to enter the destination. Illegal or clandestine entry is characterized by lack of documentation, visa, residence card or invitation to stay temporarily. All the interviewees entered illegally in the DOM. The trip can be done in a group, with a companion or alone. Through the interviews we identified that mainly women (18) migrated in groups or accompanied. According to them, being with others during the migration process makes it safer and mutual help makes the process less painful. According to the reports, it is usual for men to also travel in groups, but in the sample, the most part (39) started the process alone.

The Haitian immigration to French Guiana according to Granger (2017) became significant from the 1980s. Initially Haitians, mainly from the south, would immigrate in response to the strong demand for labor in the civil construction of the DOM. This explains the denser flows of new immigrants from this region which can be seen in the research sample. They were attracted by the network, composed by the pioneers already established in the destination country. In the 1990s, with an economic crisis and strong unemployment in French Guiana and other overseas territories, they tightened their entry requirements, preventing direct immigration with strong repression and expulsions (GRANGER, 2017).

Greater immigration control at the GF pushed the Haitian migratory flow onto the Suriname route. In this country the entrance requirement was only the tourist visa and the border is very porous via Maroni River and by road in GF. This facilitated the access to the Franco-Guyanese cities with better working options such as Cayenne and Kourou (HANDERSON, 2015). With the entry of Haiti into the Caribbean Community and Common Market (CARICON), of which Suriname is also a member, the need for a visa was suspended. According to Granger (2017, p. 53), "Haitians arrived freely in Suriname, without a visa, and then attempted to smuggle into French Guiana".

The earthquake of 2010 brought a new element to this scenario: the strong migratory flow of climate refugees, victims of the catastrophe. Brazil becomes part of the direction of this flow since, by participating in the MINUSTAH, the country could not refuse to receive Haitians in its own territory through the granting of humanitarian visas. In addition, the overheated economy, as well as the work that was being done in the Olympics and World Cup that Brazil would host in the following years, boosted the labor market of civil construction and, consequently, attracted immigrants. This intense migratory movement, according to Granger (2017), led to the formation of a Haitian neighborhood with churches that carry out their services in Creole and French in the suburbs of the city of Sâo Paulo. 
However, the migratory flow also took advantage of the route through the Brazilian territory. Since the border of Suriname was under intense surveillance by French police, the border between Amapá (Brazil) and French Guiana (France) gained relevance and allowed the union of other nodes to the Haitian migratory network. In this way, another way of entering the DOM was formed, integrating new actors and agents of the mobility of the Haitian diaspora into French Guiana.

This new path begins, for the great majority of the interviewees (57), in Port-auPrince, capital of Haiti, and others (17) left Cape Haitian. The most usual route used was to go to the Haitian city of Malpasse on the border with the Dominican Republic (DR) where the Dominican city of Jimaní is located. From there, the migrants continue to the capital of the DR, Santo Domingo. At the bus stop arriving in Santo Domingo, the interviewees reported that smugglers would promptly approach them to offer their services on to any country in South America. The smugglers services are not hired in advance, because, since it's an illegal activity, there is no predefined regularity and the relations are direct between the interested parties. The indication of friends or relatives is what counts the most when it comes to making a choice. When the migrant hires the smuggler's service, as a rule, there is no conversation in advance about which strategy will be adopted to reach the destination since, among them, there is a relationship of trust. The immigrant must have the resources to pay for the service. The payment depends on the negotiation and can be parceled out, part being paid at the beginning and another at the end or at once, at the destination.

The niche of illegal immigration demands the subcontracting of smugglers or middlemen in the transit territories of the migratory flow. In this regard, it is important to emphasize that the institutionalization of migratory networks would not be possible without the logistical activities, which have an important role to these intermediate actors of the migration system.

When migrants arrive at the South American ports, airports and bus stations, they are usually welcomed by a friend or family member and proceed to the host's house. This place of support is important for rest and to replan the route with updated information on the ways of accessing Brazil. When access is made by the North region - mainly Acre, Rondônia and Amazonas, it involves traveling on Amazonian roads that are not always paved or in good conditions. Those who do not have support on arrival will go to small, low-cost hotels.

When entering Brazil, the first step is to obtain the National Alien Registration (also known as RNE). This document is important in two cases: to be allowed to stay and to move freely within the country; or to be able to, in the absence of jobs in the Overseas Department, the immigrant can return to work in Brazilian territory until new opportunities emerge from the Guyanese side. The Haitian community already established in the Brazilian territory are the ones who receive the immigrants in transit. They provide accommodation, food, and help financially to complete the rest of the trip to the border in Amapá. This aid is paid by the migrant when settled in French Guiana and can be in the form of payment or in aid to family members of those who assisted him in a new migration process. None of the interviewees entered Brazil through Amapá, even though they all had family, friends or acquaintances in the Brazilian route. 
The transfer to the Brazilian state at the border with French Guiana is made by plane or boat - there is no road access. Those who have better financial conditions follow by plane. Once in the state capital, Macapá, the network of friends, acquaintances or relatives is again accessed. Not necessarily the migrant has direct contact with someone in Amapá (61 of the interviewees did not), usually he knows someone in GF or in Brazil that has established contact so that he can have some support, or he'll just stay in a low-cost hotel. The stay in Amapá is mostly to hire the smuggler who will take the migrant to French Guiana and, in many cases (53), to wait for relatives to send money to pay the final costs of the trip. Among those interviewed, the longest stay in Macapá was 23 days and the shortest 7 days.

The smuggler network to cross the border is in the city of Macapá and maintains contact through social media such as Facebook, WhatsApp, Twitter, Skype or direct phone connection, according to the middleman interviewed at the bus station in Macapá (field interview, 2016). The migrants, already under the smuggler's services, take a bus in Macapá towards Oiapoque - located on the border, Oiapoque is a twin city with SaintGeorges-de-l'Oyapock in French Guiana. Those who have more financial resources can

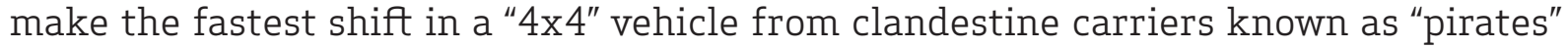
(Portuguese: piratas). As a rule, the immigrant does not stay in Oiapoque, since already at the bus station he meets with the representative of the contracted smuggler and begins the trip to French Guiana. If the migrant needs to stay in the city to wait for his turn to travel, he will stay in hostels (normally in precarious conditions) that are located near the bus station. According to reports, the costs of the border city are high, and the presence of Haitians draws attention from the authorities. Among those interviewed, 26 spent at least one night in Oiapoque. To enter the Overseas Department, immigrants will follow in pairs or individually, since big groups draw to much attention.

According to a smuggler interviewed in Macapá (field interview, 2017), there are two possibilities to reach the city of Cayenne ${ }^{13}$. The first consists of the payment of $€ 300,00$ (euros) to the smuggler to be able to cross the Oiapoque river located just in front of the city and arrive in Saint-Georges-de-l'Oyapock - the crossing takes 15 minutes - and then travel by bus. By that means, the clandestine embark in Saint-Georgesde-l'Oyapock and get off at the roadside before arriving at the military control point in the city of Régina (French Guiana). They follow by foot for approximately 6 kilometers, being necessary to cross an old bridge in very bad conditions. After this obstacle, the migrants return to the bus and travel to Cayenne. For this route to happen, the smuggler maintains contact with the catraieiro (the person who conducts the small boat named "catraia") and the bus driver who also receives money for the transport of the illegal immigrants (field interview, 2017). The risk of failure and being caught on the way is not only focused on the police station. On the road connecting Saint-Georgesde-l'Oyapock to the capital Cayenne there is a constant presence of soldiers. The diligences, police patrols, border operations and the presence of the Légionnaires ${ }^{14}$ in the

13 The immigrants that were interviewed chose not to report the route taken to enter French Guiana through Oiapoque. And, the smuggler chose not to indicate the most commonly used possibility.

14 The French Foreign Legion is a military service branch of the French Army, created in the nineteenth century. They accept enlistments of all nationalities, having the soldier the right to anonymity as well as a new identity when enlisting. Currently, the Foreign Legion is an elite troupe with one of its headquarters based in French Guiana. 
Guyanese territory that act more violently, define the rigid social control in DOM.

The second possibility of reaching the capital of the Overseas Department is to pay $\mathrm{R} \$ 500,00$ (five hundred reais) to the smuggler and cross the Oiapoque river with the "catraia" embarking in Vila Vitoria located on the outskirts of Oiapoque in a private, yet precarious, port which is very difficult to access and then up to a meeting point ${ }^{15}$, previously combined with the taxi driver. From the meeting point, the immigrants follow with the taxi driver - this route is longer and takes between 40 minutes to an hour to arrive. The taxi driver, also contacted by the smuggler, is in charge of taking the migrant along secondary routes to the city of Cayenne. This route, although cheaper, is considered the most dangerous because of the police patrols on the way and given the strong control of the French navy and the Légionnaires by river.

In case of failure, the illegal immigrants are arrested, interrogated and deported to the border city from where they crossed, that is, in Oiapoque. None of the interviewees got caught on the way, but all of them knew at least someone who had been detained trying to get in the DOM. According to the reports, deported immigrants stay in the border city (Oiapoque) until they can find the resource to re-invade. This can last up to 60 days.

The porosity of the borders of French Guiana and Amapá and the constant interaction between the twin cities are elements that facilitate the movement of immigrants towards the DOM. In the frontier territory of Oiapoque there are always people arriving, waiting, departing; these phenomena denote the historicity of a population dynamics towards French Guiana. The outline of this mobility varies as much as the objectives of the individuals in transit (MARTINS; SUPERTI; PINTO, 2015). There are people traveling to Saint-Georges, Cayenne, Camopi, Vila Vitoria, Vila Velha, Ilha Bela, Vila Brasil, and/or to the illegal mine scattered throughout French Guiana. Traders, catraieiros, natives, shippers and residents in the communities of Ilha Bela and Vila Brasil, are the actors that most depend on the river transportation system through the Oiapoque river. The economies of both cities are structured according to the interactions they maintain among themselves.

Considering the trajectories reported by the immigrants interviewed, we identified five distinct migratory routes (Table 2 and Figure 1). The first leaves the Haitian capital and passes through the Dominican Republic and Brazil before arriving at the final destination; the second route most used by the immigrants interviewed in the city of Cayenne leaves the city of Cape Haitian, passing through the Dominican Republic and Brazil; Port-au-Prince, Dominican Republic, Ecuador and Brazil is the fourth most used route; Port-au-Prince, Dominican Republic, Chile, Argentina and Brazil was the fifth route most used by immigrants; and, finally, we identified the route of Port-auPrince, Panama, Brazil, that was used by only one Haitian immigrant.

15 The meeting point with the taxi driver is not always the same. Anyhow, the location was not revealed by the smuggler and the immigrants did not know precisely either. 
Table 2 - Migration routes used by Haitian immigrants to French Guiana.

\begin{tabular}{lccc}
\hline \multicolumn{1}{c}{ Trajectories } & Men (54) & Women (20) & Both sexes combined \\
\hline Port-au-Prince / DR / BR / GF & 22 & 20 & 42 \\
Cape Haitian / DR / BR / GF & 17 & 0 & 17 \\
Port-au-Prince / DR / Ecuador / BR & 8 & 0 & 8 \\
Port-au-Prince / DR / Chile / ARG / BR / GF & 6 & 0 & 6 \\
Port-au-Prince / Panama / Brazil / GF & 1 & 0 & 1 \\
Total & $\mathbf{5 4}$ & $\mathbf{2 0}$ & $\mathbf{7 4}$ \\
\hline
\end{tabular}

Source: Research questionnaires applied in 2015-2016.

Figure 1 - Main routes of Haitian immigration to French Guiana in the 21st century

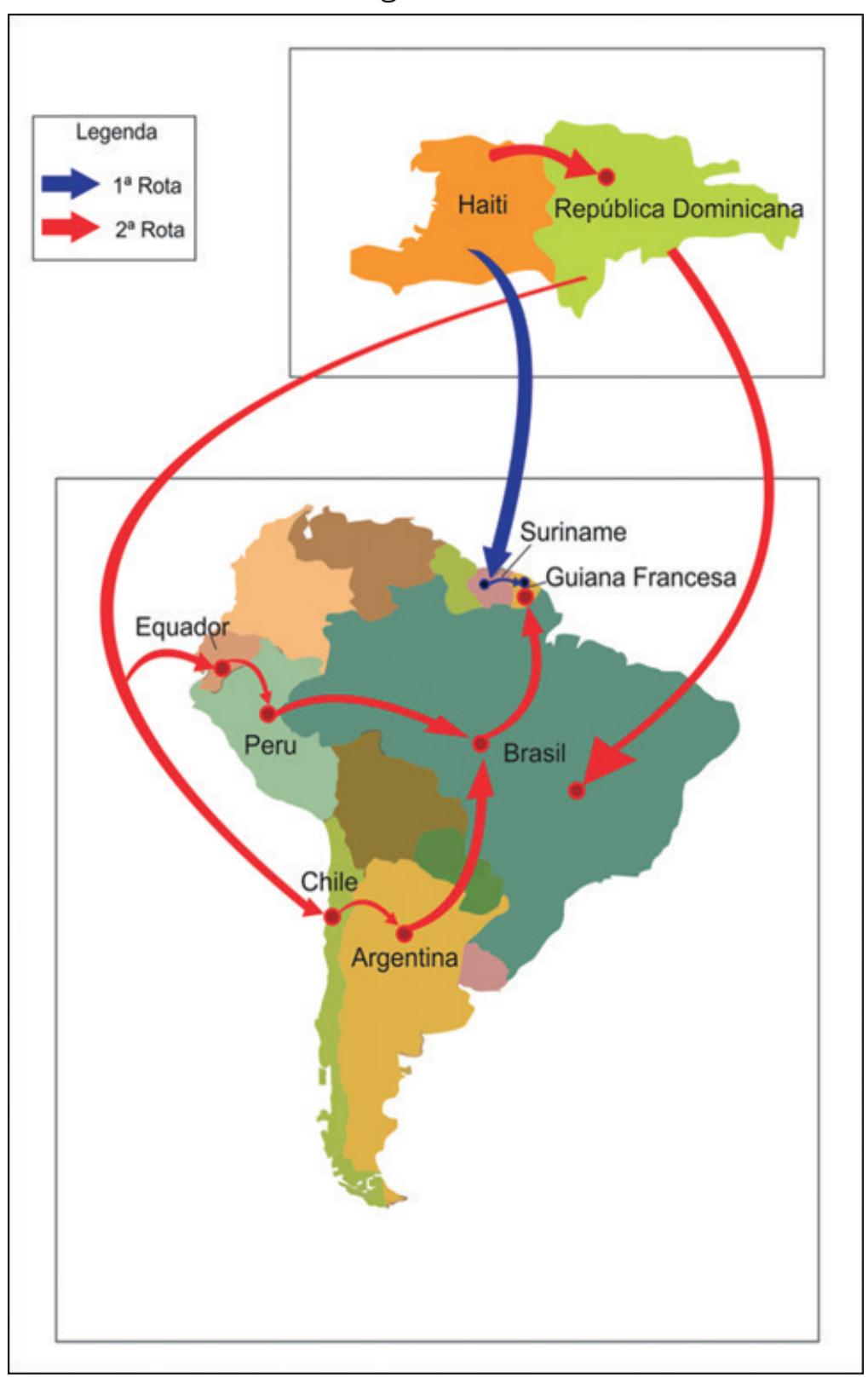

Source: Andrevil Isma (2016). 
The endpoint of the route is at the city of Cayenne, capital of GF. Other destinations are possible, but the contract with smugglers ends when arriving at the capital of the DOM. For the interviewees, all were received by relatives or friends in the capital and were already linked to them by the migration network. Haitians in French Guiana occupy neighborhoods on the suburbs of the city. Culturally, Haitians establish housing in groups (ISMA, 2016), forming a community within the destination society, called lakou. For this reason, Haitian neighborhoods are often known as Petit Haiti.

Among the interviewees, 51 were in the Cogneau Lamirande neighborhood. The others were distributed in other neighborhoods ${ }^{16}$ also with a strong Haitian presence. The Cogneau Lamirande neighborhood is considered by the Haitians who were interviewed as a territorial extension of southern Haiti and is one of the main Haitian neighborhoods in Cayenne.

The family and friends networks were fundamental for the support in the arrival of the interviewees. Some of them (23) reported arriving at Cayenne with no money and the others with an insufficient amount to settle without the support of family and friends who already work there. Although this was not the situation of the interviewees, they reported that immigrants who do not have family members or friends who are economically stable and that are able to receive them seek even more peripheral neighborhoods with poor infrastructure to settle, since housing is expensive in the Overseas Department (DOM) and due to the illegal situation.

The migration network forms a support and protection shield for the illegal immigrant: the more consolidated the network, the stronger this protection will be, as well as the articulation to insert him into the labor market. This is a fundamental condition to guarantee not only the new immigrant in the territory, but also the living conditions of those who receive him. According to the interviewees, the costs can not be sustained for a very long time and finding work is a priority. This pushes them to accept any job offer.

The insertion in the job market is always in a condition of subordination and precariousness, as an illegal worker and with below average salaries. According to the French NGO La Cimade ${ }^{17}$, it is not uncommon to see the disrespect of human rights and injustices happening in working relations with Haitian immigrants (field interview, 2017). The NGOs play an important role in monitoring exploitation situations and facilitate access to the labor market, either directly, through contacts, or through qualification and language teaching efforts. The non-governmental organization makes up the protective shield to the fragile living condition of the illegal immigrant.

The agents of the migration network are many and immigration is a multifaceted process. The relation of the immigrants with their family and friends gives life to the main nodes of the system, which forms its structure. But it would not work without the presence of the smugglers/middlemen who maintain the logistical and operational schemes of the active displacement, constituting an illegal market of services offered

16 The neighborhoods that the other interviewees addressed were Rémire-Montjoly (4), Mango (9), Cité Bonhomme (8), Arc en Ciel (2).

17 La Cimade is a French NGO founded at the beginning of the World War II. The non-governmental organization works with uprooted people, especially undocumented immigrants in France and its departments. 
and organized throughout the network. The tacit migratory contract guarantees its continuity and influence the migration flow for a given destination since the cheaper contracts tend to be the most voluminous considering it is a displacement of individuals and families strongly impoverished in their country of origin. The network also establishes, although fragile, protection and insertion mechanisms where, once again, family and friends are fundamental as well as the presence of institutions such as NGOs.

\section{FINAL CONSIDERATIONS}

The history of the political-social formation of the Haitian State, its economic fragility and the natural catastrophes, marked by the earthquake of 2010, is the scenario that has led to the intensification of Haitian migratory flows throughout the South American subcontinent. Diaspora network agents, considering the normative reality and their choices, have reoriented the mobility strategies used by this flow. It is from that moment on that territories which were previously irrelevant to this movement become strategic like Amapá on the border between Brazil and GF.

The decision of the migratory act was consolidated in Haiti as a comprehensive strategy with cultural, economic and relational variables. It involves multiple agents and institutions from the place of origin to the destination. Its dynamics can not be understood only from the classical view of theories of international immigration. The perspective brought by migratory networks allows us to understand how actions and social relationships of these agents organized in a network give life to migratory movements without disregarding the structured reality where the phenomenon occurs. They are individuals, family groups, non-governmental organizations (NGOs), smugglers, middlemen, and the Haitian receiving community all in an articulated and united movement. This movement gained more dynamism through the mechanisms and structures of the network society, since the technological revolution significantly reduced and diversified the costs of communication and transportation, indispensable requisites in the dynamics of migration networks.

Thus, in the perception of this work, the migratory networks are the "modus operandi" of the Haitian migratory flow towards French Guiana with a route through the northern Brazilian Amazon. Brazil, and specifically Amapá, were included as important nodes in the system of this network. 


\section{BIBLIOGRAPHY}

BERNARTT, M. de L; PEZARICO, G; PIOVEZANA, L; BORDIGNON, S. de Á. F; GIACOMINI,T. Diáspora Haitiana: Primeiros Estudos sobre Impactos para o Desenvolvimento Urbano e Regional nas Regiōes Sul e Norte do Brasil. In Cadernos Ceru, v. 26, n. 1, p 101-125, 2016.

BOURDIEU, Pierre. Le capital social. In: Actes de la recherche en sciences sociales. Vol. 31, 1980.

CASTELLS, M. A sociedade em rede. 2ª ediçáo, Sáo Paulo: Paz e Terra, 1999.

DUARTE, G. R. Guiana Francesa: uma análise geohistórica. In Confins. Vol. 28, 2016.

FERNANDES, D. (Coord.); CASTRO, M. da C. G. de. Estudos sobre a Migraçăo Haitiana ao Brasil e Diálogo Bilateral. Belo Horizonte, 2014. Retrieved from: <http://portal.mte.gov. br>. Accessed: Aug. 23rd, 2015.

GRANGER, S. As Migraçōes de Haitianos na Guiana Francesa: Novas Dinâmicas. In Temáticas. Campinas, vol. 25, n. 49/50, p. 49-62, 2017.

GUILMOTO, C.Z;SANDRONF.The Internal Dynamics of Migration Networks in Developing Countries. In: Population: an English selection, 13 année, n², 2001. p. 135-164.

INTERNATIONAL CRISIS GROUP. Consolidating Stability in Haiti. Latin America/ Caribbean Report N²1 - 2007. Retrieved from: 〈https://www.crisisgroup.org/latin-america-caribbean/haiti/consolidating-stability-haiti>. Accessed: Oct. 30, 2018.

JOSEPH. H. Diáspora. As dinâmicas da Mobilidade haitiana no Brasil, no Suriname e na Guiana Francesa. Rio Janeiro: UFRJ/Museu Nacional, 2015, 150 p.

KELLY, P. F. Social and cultural capital in the urban ghetto: implications for the economic sociology of immigration. In PORTES, A. (org.). The economic sociology of immigration. Nova York, Russell Sage, 1995.

LEVI, G. (2001), On microhistory. In BURKE, Peter (org.). New perspectives on historical writing. The Pennsylvania State University Press, 2001.

MARTINS, C. das C.SUPERTI, E.PINTO, M. de J. de S. Migraçăo e Mobilidade de Brasileiros Através e Além da Fronteira Brasil-Guiana Francesa. In: TOMO, n. 27, 2015, p. 361-396.

MASSEY, D. S, ARANGO, J. HUGO, G. KOUAOUCI, A. PELLEGRINO, A. TAYLOR, E. Theories of International Migration: A Review and Appraisal. In: Population and Development Review, vol. 19, no. 3, 1993, p. 431-466.

PIANTONI, F. Migrants en Guyane, Arles/Caiena: Actes Sud/Maison des Cultures guyanaises, 2011.

WORLD BANK. The Migration and remittance fact book. World Banck Washington, 2011. Retrieved from: <http://siteresources.worldbank.org>. Accessed: Oct. 30, 2018. 